\title{
Setting of graded levels of a protein in yeast by a t-degron technique as applied to phosphoglycerate mutase Katja Heidrich ${ }^{1,2}$ and Dan G Fraenkel*1
} \author{
address: Inst. fur Klinische Immunologie, Univ. Leipzig, Johannisallee 30, Leipzig 04103, Germany \\ E-mail: Katja Heidrich - kheid@server3.medizin.uni-leipzig.de; Dan G Fraenkel* - fraenkel@ hms.harvard.edu \\ *Corresponding author
}

Address: ${ }^{1}$ Dept. of Microbiology and Molecular Genetics, Harvard Medical School, 200 Longwood Ave., Boston MA 02115, USA and ${ }^{2}$ Present

Published: 30 July 2002

BMC Genetics 2002, 3:13
Received: 8 May 2002

Accepted: 30 July 2002

This article is available from: http://www.biomedcentral.com/I47I-2/56/3/13

(C) 2002 Heidrich and Fraenkel; licensee BioMed Central Ltd. This article is published in Open Access: verbatim copying and redistribution of this article are permitted in all media for any non-commercial purpose, provided this notice is preserved along with the article's original URL.

\begin{abstract}
Background: Setting of graded levels of a protein for in vivo studies by controlled gene expression has inconveniences, and we here explore the use of the t-degron technique instead.

Results: In a yeast t-degron (ubiquitin-argDHFR ts)- phosphoglycerate mutase (GPMI) fusion strain, increasing periods of exposure to the non-permissive temperature $37^{\circ} \mathrm{C}$, even in the presence of cycloheximide, gave decreasing function, as assessed at $23^{\circ} \mathrm{C}$ in vivo by glucose metabolism and confirmed by immunoblot.
\end{abstract}

Conclusion: An ideal system would set a range of lower levels of a protein, do so without compensating protein synthesis, and give stable activity for in vitro comparisons. Although the first two aims appear obtainable, the third was not in this example of the application, limiting its uses for some but not all purposes.

\section{Background}

Modeling of metabolism - the matching of enzyme and physiology - is a familiar theme in biochemistry and can be an exacting exercise even for the long studied glycolytic pathway $[1,2]$. A contribution of genetics would be to supply strains with altered levels of a particular enzyme as desired. Knock-outs are inappropriate for quantitative study of the reaction itself, and although increases are readily got with cloned genes on multicopy vectors, with many enzymes in apparent excess lowered levels are of more interest. In an earlier report we have assessed glucose metabolism in yeast $\mathrm{gcr}$ mutants where levels of several glycolytic enzymes are decreased [3] and a logical next step was to arrange their individual decreases.
The usual way to decrease an enzyme level is to change expression of the gene by promoter alteration or regulation. Apart from the practicalities, such methods have the limitation that since the adjustment is a process that must occur during growth, compensating enzymes, known or not, can also change in level. So for some purposes conditional activity is preferred over conditional expression. Rather than a temperature sensitive enzyme, which is not suited for graded levels of activity, we here report application of the $t d$-mutant technique of Dohmer et al. [4], where the temperature-inactivated degron, a ts-version of mouse-dihydrofolate reductase carrying an $\mathrm{N}$-terminal arginine residue, is placed between ubiquitin and a protein of interest (POI), i.e., a Ub-td-POI gene construction, giving a td-POI protein fusion (the ubiquitin is postranslationally cleaved) which is stable at $23^{\circ} \mathrm{C}$ but degraded at $37^{\circ} \mathrm{C}$. 
Table I: Growth. Wild type, td-Gpm mutant, and ubrl-suppressed mutant were assessed at three temperatures in enriched or minimal medium with $1 \%$ glucose.

\begin{tabular}{|c|c|c|c|c|c|c|c|c|c|c|c|}
\hline & & & & Id type & & & n Mutan & & ubrl-S & essed I & \\
\hline & & & $24^{\circ} \mathrm{C}$ & $30^{\circ} \mathrm{C}$ & $37^{\circ} \mathrm{C}$ & $24^{\circ} \mathrm{C}$ & $30^{\circ} \mathrm{C}$ & $37^{\circ} \mathrm{C}$ & $24^{\circ} \mathrm{C}$ & $30^{\circ} \mathrm{C}$ & $37^{\circ} \mathrm{C}$ \\
\hline Medium R & col., 3d & $\mathrm{mm}$ & 1.7 & 2.8 & 3 & 1.4 & 2.2 & 0.1 & 1.5 & 2.1 & 3.2 \\
\hline$"$ & & $h^{-1}$ & ND & 0.39 & 0.39 & ND & 0.37 & 0.07 & ND & 0.41 & 0.41 \\
\hline " & $v_{\text {glucose }}$ & umol*h-1* ODU-1 & ND & 2.7 & 2.9 & ND & 1.4 & ND & ND & 2.7 & 2.7 \\
\hline Medium M & $\begin{array}{l}\text { glucose } \\
\text { col., 3d }\end{array}$ & & 1.1 & 1.6 & 1 & 0.8 & 0.7 & $<0.1$ & 1 & 1.5 & 1.1 \\
\hline$"(+$ Ant A) & col., 3d & & 0.3 & 0.9 & 1.1 & 0.2 & $<0.1$ & $<0.1$ & 0.3 & I & 0.8 \\
\hline$"(+$ Ant A) & col., 5d & & I & 1.7 & 1.9 & 0.7 & $<0.1$ & $<0.1$ & 1 & 1.5 & 1.3 \\
\hline
\end{tabular}

ND, not done. Col., average colony size in $\mathrm{mm}$ at the indicated time of incubation, using plates spread with not more than 50 cfu. $v_{\text {glucose }}$ is the rate of glucose metabolism. Ant A, antimycin A, $2 \mathrm{ug} / \mathrm{ml}$.

The method has been fairly widely employed to knock out a POI (e.g., by an hour's treatment at $37^{\circ} \mathrm{C}$ ), and it is known from in vitro assessment that intermediate times of treatment can give intermediate levels of activity [5,6]. For cell processes which do not require protein synthesis and glucose metabolism is one of them - it is possible that in vivo studies with intermediate activity levels could therefore be accomplished by restoration to $23^{\circ} \mathrm{C}$ in a non-growing condition, preventing further degradation or replenishment of the activity, with the functional assessment being done at the lower temperature. Furthermore, if the $37^{\circ} \mathrm{C}$ inactivation process did not require protein synthesis either, the inactivation could also be done in the non-growing condition and thus nominally allow the adjustment of enzyme levels without compensating induction of other proteins.

We test with partial success those two possibilities, using the glycolytic enzyme phosphoglycerate mutase (gene GPM1), a step whose single knock out greatly impairs glucose growth and metabolism and which is also particularly affected by $g c r$ mutations.

\section{Results and Discussion}

As shown in Table 1, the expected td-Gpm mutant phenotype was obtained, i.e., major growth impairment at $37^{\circ} \mathrm{C}$ and restoration by $u b r 1$. Depending on the test, growth of the mutant was somewhat impaired at $30^{\circ} \mathrm{C}$, as shown best by the extra sensitivity to the respiration inhibitor antimycin A. Growth was marginally abnormal even at the nominally permissive $23^{\circ} \mathrm{C}$.

Glucose metabolism, at $23^{\circ} \mathrm{C}$, in resting cells $[3,7]$ was first assessed with cells grown at $23^{\circ} \mathrm{C}$ but pretreated in growth medium for an additional period of $30 \mathrm{~min}$ at $37^{\circ} \mathrm{C}$ (or, control, $23^{\circ} \mathrm{C}$ ). As shown in Fig. 1, from both temperatures the wild type strain showed similar glucose metabolism and the usual low glycerate-3-P concentration. By contrast, lower panels, the $37^{\circ} \mathrm{C}$-pretreated mutant suspension was considerably lowered in its rate of glucose metabolism and glycerate-3-P was accumulated to high level, as in a phosphoglycerate mutase mutant [3]; the control cells not exposed to $37^{\circ} \mathrm{C}$ showed slightly elevated levels of this metabolite. The decrease in glucose flux, $v$, in the test situation of non-growing cells at $23^{\circ} \mathrm{C}$, depended on time of previous exposure to $37^{\circ} \mathrm{C}$, with, e.g., values of 0.76 (no exposure to $37^{\circ} \mathrm{C}$ ), 0.24 (30 min exposure), 0.09 (60 $\mathrm{min}$ ) and $0.03(90 \mathrm{~min})$. Thus it appears that inactivation of the reaction in vivo was stopped by restoration to the lower temperature.

To get graded levels of a protein by timed exposure to the higher temperature in a condition when new proteins were not made, the simplest protocol would be for the $37^{\circ} \mathrm{C}$ treatment to use the same non-growing condition as employed anyway for assessing metabolism - a buffer containing cycloheximide - before returning to the lower temperature for the functional testing. But this failed: a v value of 0.49 of an untreated suspension of the mutant was about the same, 0.41 , after a 90 min pretreatment at $37^{\circ} \mathrm{C}$, perhaps because inactivation by ubiquitination and proteosome function needs ATP, which is depleted in starvation. Indeed, when glucose was also present during the pretreatment of the inhibited cells at $37^{\circ} \mathrm{C}$, then the desired range of glucose fluxes was obtained in the subsequent test at $23^{\circ} \mathrm{C}$, Fig. 2, with prominent glycerate-3-P accumulation.

Unfortunately, in vitro assay of phosphoglycerate mutase activity gave variable levels in the range of $0-5 \%$ even for the mutant not exposed to $37^{\circ} \mathrm{C}$ - in spite of its almost normal glucose metabolism - and similar marginal values 


\section{Wild-type}

\section{0 min pretreated}

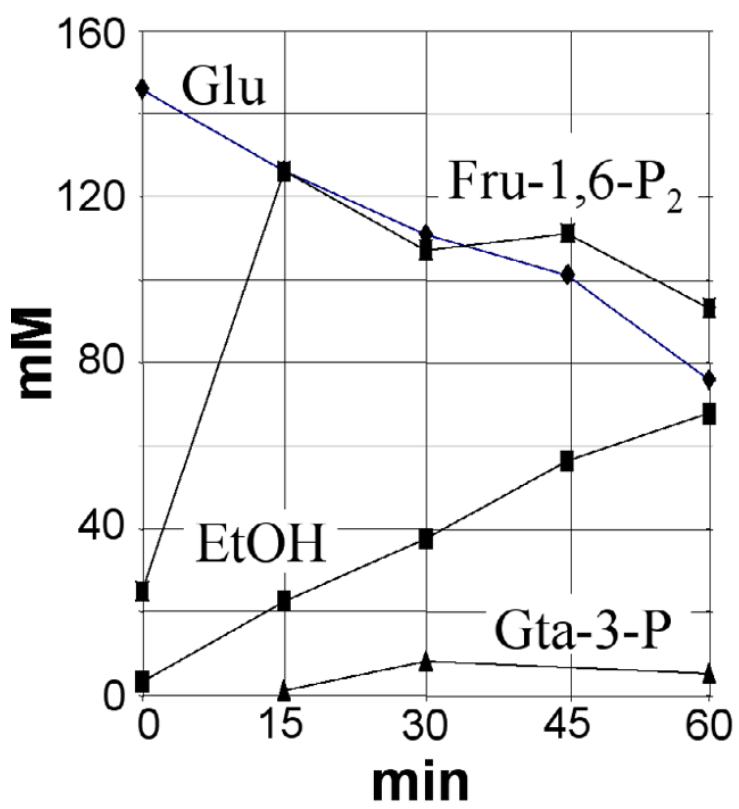

$30 \mathrm{~min}$ pretreated

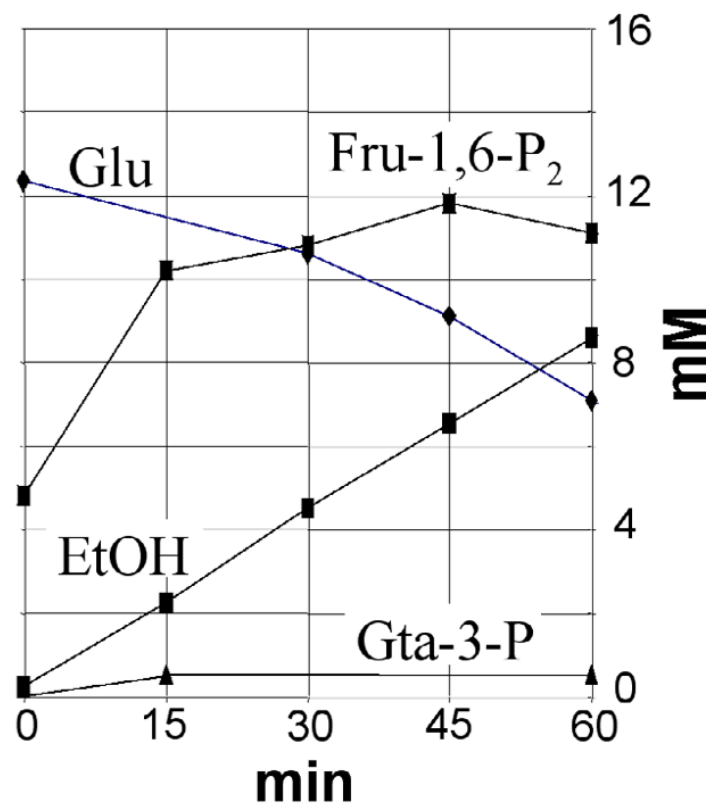

\section{Mutant}

0 min pretreated

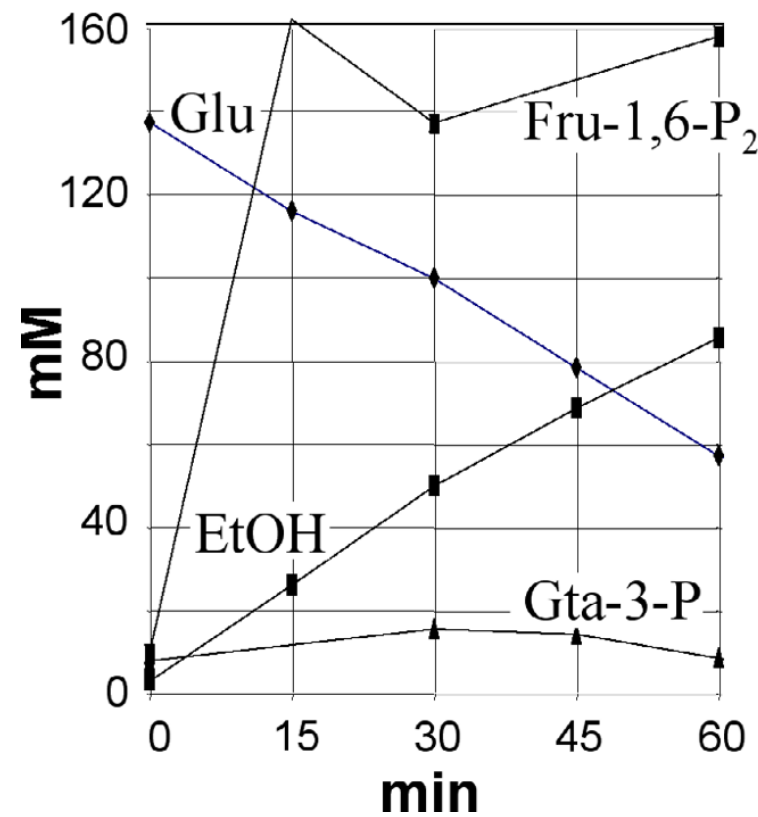

$30 \mathrm{~min}$ pretreated

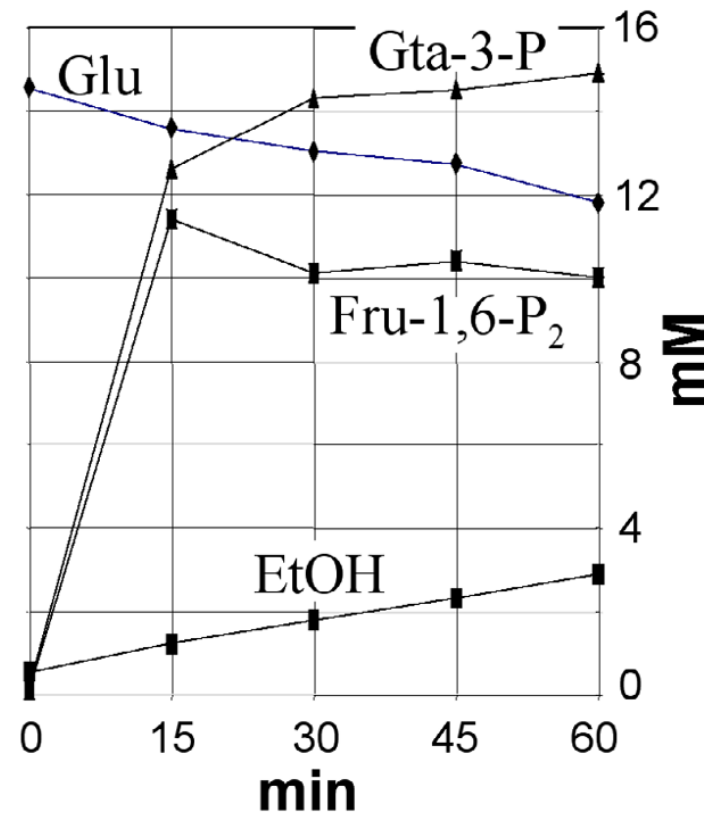

Figure I

Glucose metabolism at $23^{\circ} \mathrm{C}$ after pretreatment in growth medium at $37^{\circ} \mathrm{C}$. The control cultures, left hand panels, were similarly handled, but at $23^{\circ} \mathrm{C}$. Left hand axes are for glucose or ethanol, $\mathrm{mM}$ in medium; right hand axes for fructose-I,6-P 2 (FruI,6-P 2 ) and glycerate-3-P (Gta-3-P), $\mathrm{mM}$ in cells. 


\section{0 min pretreated}

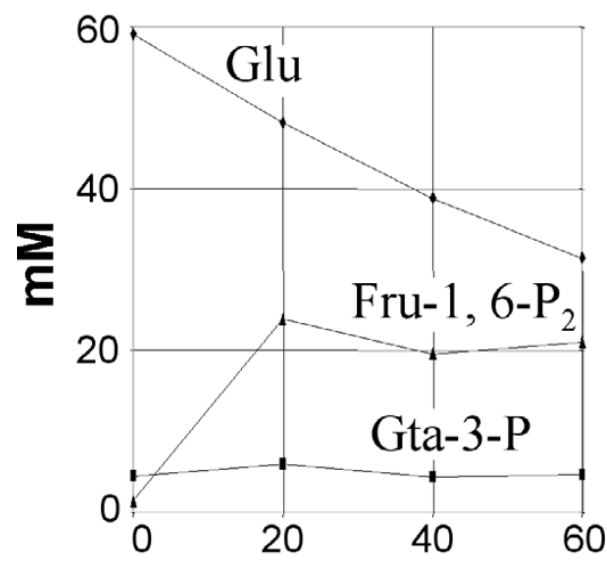

20 min pretreated

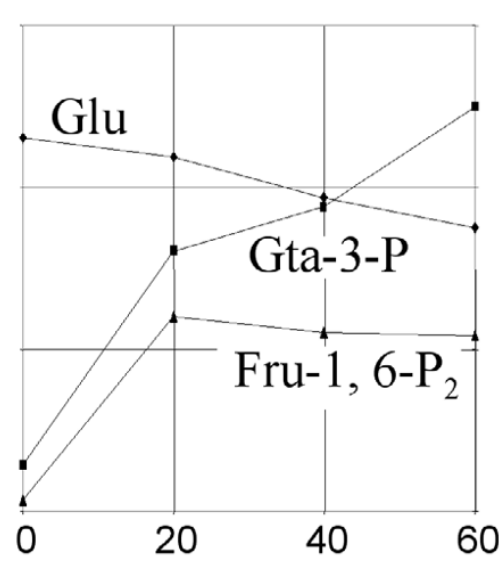

60 min pretreated

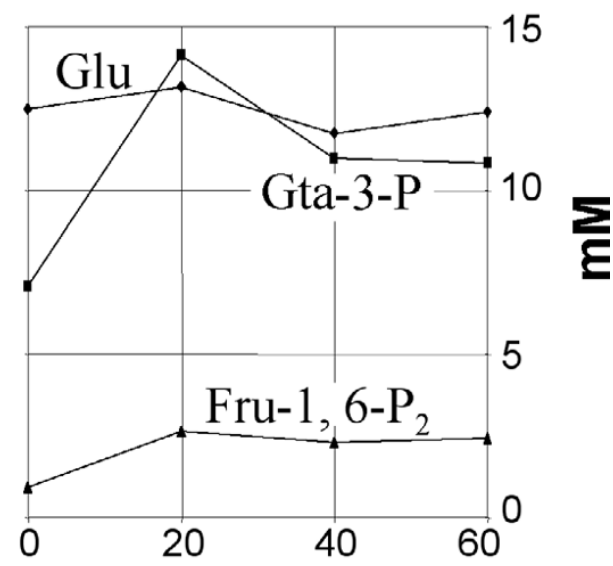

\section{$\min$}

\section{Figure 2}

Glucose metabolism in the mutant at $23^{\circ} \mathrm{C}$ after pretreatment at $37^{\circ} \mathrm{C}$ in the non-growing condition with glucose. Other details are as in Fig. I.

were also found with the ubr1-suppressed mutant. These results likely reflect in vitro lability of the td-Gpm fusion protein, which therefore had to be measured as antigen. As shown by immunoblot (Fig. 3), the strains with tdGpm substituted for normal Gpm only showed the expected larger fusion protein. For the cultures not exposed to $37^{\circ} \mathrm{C}$ (left hand four lanes), in line with the signs of some growth impairment even at permissive temperature, the signal in the mutant was much lower than wild type (ca. 10\%, by comparison of two-fold dilutions); it was somewhat higher in the ubr1-suppressed mutant. As expected, a $37^{\circ} \mathrm{C}$ preincubation (right hand four lanes) had little effect in wild type but substantially reduced the mutant signal - unless the strain also carried $u b r 1$.

Thus, both starting expectations were met: intermediate levels of a POI could be provided for in vivo study and the adjustment even done in non-growing conditions. However, the method has several disadvantages at present. The clearly low level of fusion protein even in the ubr1-suppressed mutant grown at $23^{\circ} \mathrm{C}$ suggests low expression. D. Finley has pointed out that the new NdeI site (see Methods) might have impaired translation initiation; this problem could be avoided by a different construction. It may also be that although the GPM1 promoter is very strong, other disadvantages of the fusion, such as non-ideal codon usage in the degron might require compensation by overexpression. We used, but did not have to, the normal promoter and normal chromosomal context. By contrast, most genes are expressed at far lower level than GPM1 and most td work has used the CUP1 promoter.
One attraction of t-degron methods is portability, the same construction being effective with many POI's - as seen in its uses for functional knockout by temperature, the large $\mathrm{N}$-terminal td extension being acceptable for many proteins. The same generality would be anticipated to the use suggested here to setting of intermediate levels. However, in general quantitation of function of fusion proteins has been limited, and it may be that even with improved expression the method will not be widely useful for our original aim, which was to obtain different levels of stable activity characterizable in vitro for purposes of modeling. But those properties are not needed in all applications, and many proteins are not assayed by their activity in vitro anyway.

Regarding phosphoglycerate mutase, the present results suggest that a level in the $10 \%$ range is adequate. That value would be a maximum, since the specific activity of the fusion protein is not known. A strain with mutant Pgm and $0.7 \%$ of wild type activity level grew in YEPD medium at $1 / 5$ the wild type rate [8], and a strain with GPM1 under pGAL control and 3\% of normal activity grew adequately on galactose [3]. These numbers emphasize the need for methods to set enzyme levels, and suggest that at least for phosphoglycerate mutase a low range will be of interest.

\section{Conclusion}

This report is a first step in adapting the portable t-degron system to use in setting up of intermediate enzyme activities rather than knock-out. The most useful system would allow setting of a range of lower levels of a protein, do so without compensating protein synthesis, and give stable 


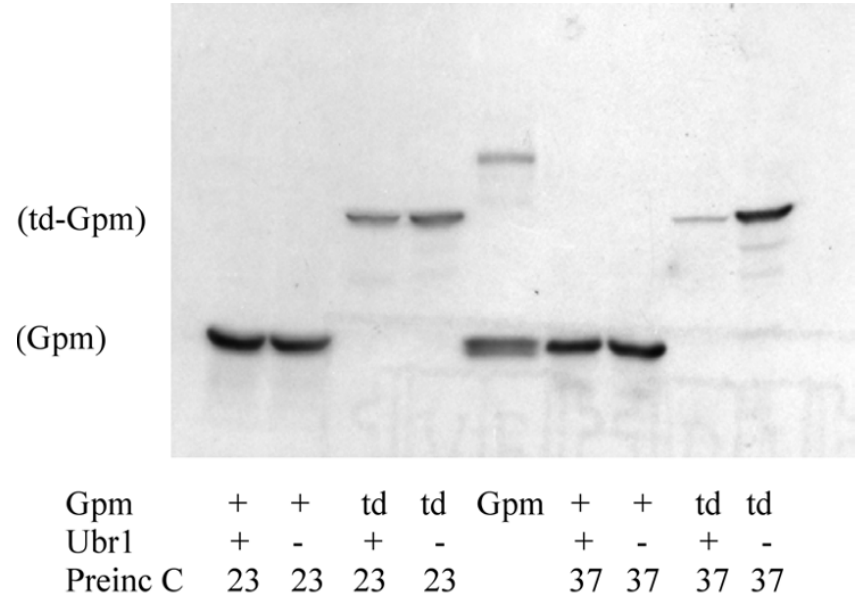

\section{Figure 3}

Immunoblot with anti-phosphoglycerate mutase antiserum. Pretreatment was in the resting cell condition with glucose for $70 \mathrm{~min}$ at $23^{\circ} \mathrm{C}$ (left hand four extracts) or $37^{\circ} \mathrm{C}$ (right hand four extracts). The middle lane is a sample of purified phosphoglycerate mutase. Both wild type UBRI and mutant ubrl backgrounds were used.

activity for in vitro comparisons. Although the first two aims appear obtainable, the third one was not in this example of the application, which limits its uses for some purposes.

\section{Methods}

The "wild type" strain is HD162-5A [9] and the "td-Gpm mutant" is a derivative, DFY758, with Ub-td inserted at the initiation codon of the phosphoglycerate mutase gene GPM1 in normal chromosomal context. The construction was (i), to make a plasmid with Ub-td flanked by NdeI sites (so that the same fragment could be inserted at any suitably modified ATG). Plasmid pPW66R (from R Dohman [4]) carries pCUP1-Ub-ArgDHFR ${ }^{\text {ts }}$ - ha-CDC28 ${ }_{1-}$ 95 in YIpRS306, and a NdeI-bounded 897 bp fragment (from ATG of Ub to ATG of CDC28) was obtained by PCR using ( $5^{\prime}$ to $3^{\prime}$ ) primers CTTTAACTAATAGCATATGCAGATTTTCG and TTCACCGCTCATATGCCCGGAAGCTT and cloned into the NdeI site of pUC19. (ii) The EcoR1 insert from GPM1/YEp352 (from H Uemura), a 2076 fragment with GPM1(YKL152C), 737 bp, flanked by 1001 bp $5^{\prime}$ and 346 bp 3', was subcloned into pUC19 with its NdeI site removed by fill-in. An NdeI site was then introduced at the initiation codon of GPM1, using two back-to-back primers at bp12 of the ORF, 5' to 3', AACTTTGGCATATGTGTAATATGTGT and AGTTTTAGTTAGACACGGTCAAT and PCR followed by ligation, confirmed by sequencing, and the NdeI Ub-td fragment was introduced at the new site and its orientation and junction likewise confirmed. Its 2792 bp EcoRI [1001 bp 5'/ Ub-td-GPM1/157 bp 3']
SalI fragment was placed into YipRS306, cut with BglI (bp 485 of GPMI) and transformed into the wild type strain with $\mathrm{Ura}^{+}$selection on glucose at $30^{\circ} \mathrm{C}$. Candidate integrants were grown in enriched medium with glucose at $23^{\circ} \mathrm{C}$, and strain DFY758 was identified as an FOA ${ }^{\mathrm{r}}$ (Ura) segregant which was ts in growth on glucose. Ubr1p is a recognition component for degradation of td constructs, and a td-Gpm 1 ubr1 strain (DFY760) contains ubr1::HIS3 introduced by transplacement from pJDubrdelta4-b (from R.J. Dohmen); its growth was not temperature sensitive. For comparison, ubr1 was also placed in the wild type UBR1 background (strain DFY655).

Growth and analysis of glucose metabolism was as described [3,7]. Enriched medium R (buffer B61, 0.4\% Difco yeast extract, $1 \%$ Difco tryptone) supplemented with $1 \%$ glucose was used throughout, except for the minimal medium M (buffer B61 and 0.67\% Difco yeast nitrogen base plus needed supplements) entries in Table 1. Incubations with resting cells, at $23^{\circ} \mathrm{C}$, used suspensions at 50-150 $\mathrm{ODU}_{580} / \mathrm{ml}$ in buffer B61 containing cycloheximide (10 $\mathrm{ug} / \mathrm{ml})$ and antimycin A ( $2 \mathrm{ug} / \mathrm{ml})$. Rates of glucose metabolism, $\mathrm{v}$, are given as umoles/h/ODU, and cytoplasmic concentrations of metabolites were normalized to ODU [3]. Pretreatment at $37^{\circ} \mathrm{C}$ was (Fig. 1) in growth medium or (Fig. 2) in the resting cell condition and was followed by washing and the usual incubation with glucose at the lower temperature. For antibody, S. cerevisiae phosphoglycerate mutase (from L. Gilmore [8]) was obtained (Covance Research Products Inc.) by the regime of 250 ug in Freund's Complete Adjuvant, followed at 3 and 6 weeks by 125 ug in Freund's Incomplete Adjuvant and with bleeds at 7 and 9 weeks; the antiserum was preabsorbed with a crude extract from a pgm1 mutant. For the immunoblot blot of Fig. 3, cells grown at $23^{\circ} \mathrm{C}$ were preincubated $70 \mathrm{~min}$ at $23^{\circ} \mathrm{C}$ or $37^{\circ} \mathrm{C}$ in buffer 61 with cycloheximide $(10 \mathrm{ug} / \mathrm{ml})$ and $1 \%$ glucose, and then washed and reincubated $1 \mathrm{~h}$, both at $23^{\circ} \mathrm{C}$, in the resting cell buffer with $1 \%$ glucose. The cells were then resuspended at $100 \mathrm{ODU} / \mathrm{ml}$ in SDS gel sample buffer containing $100 \mathrm{mM}$ DTT, heated $5 \mathrm{~min}$ at $95^{\circ} \mathrm{C}$ and treated $50 \mathrm{sec}$. with glass beads, and $10 \mathrm{uL}$ amounts used in SDS-PAGE, employing Biorad broad range prestained standards. Blotting was to Millipore Immobilon P transfer membrane, blocking with condensed milk, and after incubation with the anti-Gpm antiserum detection by the Amersham ECL method with HRP-labeled goat anti-rabbit antibody.

\section{Acknowledgements}

We thank RJ Dohmen, H Uemura, G Chen, L Gilmore, T Kriegel, and D Finley. Supported in part by the William F Milton Fund and, $\mathrm{KH}$, by the German Academic Exchange Service (DAAD).

\section{References}

I. Kashiwaya Y, Sato K, Tsuchiya N, Thomas S, Fell DA, Veech RL, Passonneau JV: Control of glucose utilization in working rat heart. J Biol Chem 1994, 269:25502-255 I4 
2. Teusinck $B$, Passarge J, Reijenga $C A$, Esgalhado $E$, van der Weijden CC, Schepper M, Walsh MC, Bakker BM, van Dam K, Westerhoff HV, Snoep JL: Can yeast glycolysis be understood in terms of in vitro kinetics of the constituent enzymes? Testing biochemistry. Eur J Biochem 2000, 267:5313-5329

3. Uemura $\mathrm{H}$, Fraenkel DG: Glucose metabolism in gcr mutants of Saccharomyces cerevisiae. J Bacteriol 1999, I 8 I :47 I 9-4723

4. Dohmen RJ, Wu P, Varshavsky A: Heat-inducible degron: a method for constructing temperature-sensitive mutants. Science 1994, 263: | 273-1276

5. Huang W, Feaver WJ, Tomkinson ASE, Friedberg EC: The n-degron protein degradation strategy for investigating the function of essential genes: requirement for replication protein $A$ and proliferating cell nuclear antigen proteins for nucleotide excision repair in yeast extracts. Mutation Research 1998, 408:183194

6. Guttmann-Raviv N, Boger-Nadjar E, Edri I, Kassir Y: Cdc28 and Ime2 possess redundant functions in promoting entry into premeiotic DNA replication in Saccharomyces cerevisiae. Genetics 200I, 159:1547-1558

7. Benevolensky S, Clifton D, Fraenkel DG: The effect of increased phosphoglucose isomerase on glucose metabolism in Saccharomyces cerevisiae. J Biol Chem 1994, 269:4878-4882

8. White MF, Fothergill-Gilmore LA: Development of a mutagenesis, expression and purification system for yeast phosphoglycerate mutase. Investigation of the role of active-site His I 8I. Eur J Biochem 1992, 207:709-7I 4

9. Heinisch J], Muller S, Schluter E, Jacoby J, Rodicio R: Investigation of two yeast genes encoding putative isoenzymes of phosphoglycerate mutase. Yeast 1998, I 4:203-213

Publish with BioMed Central and every scientist can read your work free of charge

"BioMedcentral will be the most significant development for disseminating the results of biomedical research in our lifetime."

$$
\text { Paul Nurse, Director-General, Imperial Cancer Research Fund }
$$

Publish with BMC and your research papers will be:

- available free of charge to the entire biomedical community

- peer reviewed and published immediately upon acceptance

- cited in PubMed and archived on PubMed Central

- yours - you keep the copyright

Submit your manuscript here:

http://www.biomedcentral.com/manuscript/
BioMedcentral.com editorial@biomedcentral.com 